\title{
Teknik Bedeng Permanen Alternatif Mengurangi Biaya Produksi Usahatani Pada Kondisi Pendemi Covid19
}

\author{
I Nym Soemeinaboedhy, Padusung, IGM Kusnarta, Mahrup, Fahrudin \\ Program Studi Ilmu Tanah, Fakultas Pertanian Universitas Mataram, Mataram, Indonesia
}

\author{
Article history \\ Received: 01-11-2021 \\ Revised: 15-11-2021 \\ Accepted: 17-11-2021 \\ *Corresponding Author: \\ Iym Soemeinaboedhy, \\ Fakultas Pertanian/Universitas \\ Mataram, Mataram, \\ Indonesia; \\ Email: \\ isoemeinaboedhy@yahoo.com
}

\begin{abstract}
Permanent raised-beds can be used in several soil seasons and aim to increase production through the application of sustainable and sustainable agriculture and can improve the welfare of farmers. The three basic principles of conservation agriculture are: i) applying minimal or no tillage ii) applying cover crops continuously throughout the year, and iii) applying crop diversification, either by intercropping, crop rotation, and consecutive cropping (relay cropping), especially between non-legume and legume crops. Service activities provide knowledge to farmers by demonstrating the application of permanent bed farming techniques to reduce farm production costs. This activity is expected to: 1) as an example of the application of permanent bedbased agriculture to prevent soil erosion by planting cover crops and mulch, 2) as an example of a permanent bed technique to maintain soil stability and save costs, 3) as an example of a natural way to restore physical, chemical and biological fertility of dry soil, and 4) as an example of how to increase soil productivity in dry paddy fields typology. To achieve this, several conservation methods will be introduced, as well as several types of vegetable crops and minimum tillage techniques will be introduced.
\end{abstract}

Keywords: permanent; raised-bad; conservation; monimum; tillage

Abtrak: Bedeng permanen dapat digunakan dalam beberapa musim tanah serta bertujuan meningkatkan produksi melalui penerapan pertanian lestari dan berkelanjutan serta mampu meningkatkan kesejahteraan petani. Tiga prinsip dasar pertanian konservasi yakni: i) menerapkan pengolah tanah minimal atau tanpa olah tanah ii) menerapkan tanaman penutup tanah (cover crops) secara terus-menerus sepanjang tahun, dan iii) menerapakan diversifikasi tanaman, baik secara tumpang sari, rotasi tanaman, dan tanam beruntun (relay cropping), terutama antara tanaman non legume dan legume. Kegiatan pengabdian memberikan pengetahuan pada petani dengan cara mendemonstrasikan penerapan pertanian teknik bedeng permanen untuk mengurangi biaya produksi usahatani. Kegiatan ini diharapkan dapat: 1) sebagai contoh penerapan pertanian yang berbasis bedeng permanen dapat menjaga tanah agar tidak mengalami erosi dengan menanam tanaman penutup tanah (cover crops) dan mulsa, 2) sebagai contoh teknik bedeng permanen untuk memelihara stabilitas tanah dan irit biaya, 3) sebagai contoh cara alamiah dalam pemulihan kesuburan fisik, kimia dan biologi tanah tegalan, dan 4) sebagai contoh cara peningkatan produktivitas tanah pada tipologi lahan sawah kering. Untuk mewujudkan hal tersebut, maka beberapa metode konservasi akan diperkenalkan, serta akan diperkenalkan beberapa jenis tanaman sayuran dan teknis pengolahan tanah minimal.

Kata Kunci: : bedeng; permanen; konservasi; olah tanah; minimum 


\section{PENDAHULUAN}

Karakteristik anah sawah umumnya: sering digenangi, pHnya rendah atau asam, sehingga tingkat kesuburannya tanahnya rendah, lapisan olah tipis, dan solum tanah dangkal, kelembaban tanah nisbi rendah, sehingga produktivityas tanahnya rendah Bedeng permanen telah terbukti unggul diterapkan pada tanah pertanian walaupun perlu penyesuaian untuk diterapkan pada daerah-daerah tertentu. Selain itu penerapan bedeng permanen dapat menekan biaya pengolahan tanah dan juga kerusakan tanah aklibat pengolahan yang berkelanjutan (Kusnarta et al, 2011).

Petani sudah lama mengembangkan lahan sawah untuk ushataninya dan yang merupakan salah suatu agroekosistem, baik tanaman pangan, hortikultura (sayuran dan buah-buahan) maupun tanaman tahunan dan peternakan (Las et at., 2000). Berdasarkan Atlas Arahan Tata Ruang Pertanian Indonesia skala 1:1.000.000 (Pusat Penelitian dan Pengembangan Tanah dan Agroklimat 2001), Indonesia memiliki daratan sekitar 188,20 juta ha, terdiri atas 148 juta ha lahan kering (78\%) dan 40,20 juta ha lahan basah (22\%) (Soepardi, 2001)

Hilangnya unsure hara pada tanah melalui pencucian dan aliran permukaan dapat menyebabkan menurunnya produktivitas lahan (Mulyani et al. 2004). Selain itu kasus di beberapa tempat disebabkan oleh sistem ladang berpindah, dan praktik pembakaran jerami dalam penyiapan lahan. Kegiatan usahatani tanaman pangan semusim berupa padi dan jagung di lahan sawah umum dilakukan oleh para petani (Sukmana, et al., 1995).

Lahan garapan petani yang sempit kurang menguntungkan jika ditanami padi.dan untuk mengatasi masalah tersebut adalah menanam tanaman hortikultura seperti sayuran pada bedeng permanen sebagai tambahan pendapatan sehari-hari. Selanjutnya dengan teknik bedeng permanen maka kerusakan tanah dapat ditekan karena tanah diolah secara minimal atau bahkan tidak diolah secara total. Teknik bedeng permanen merupakan teknik bercocok tanam yang umum dilakukan di daerah lahan kering namun bukan berarti tidak dapat dilakukan di lahan sawah terutama pada musim kemarau (Adiningsih et al. 1983)

Untuk mengatasi permasalah tanah sawah maka alternatif yang dapat dilakukan adalah dengan menerapkan teknik bedeng permanen yaitu bedeng yang dipergunakan dalam waktu lama. Aplikasi teknik bedeng permanen dapat menekan kerusakan tanah baik secara fisik, kimia dan biologi daoat ditekan secara berangsur-angsur, dan produktivitas lahan dapat dipulihkan, baik yang diakibatkan oleh proses alamiah maupun faktor antrofogenik. (Abdurachman dan Santoso, 2005).

\section{METODE}

\section{Metode Pelaksanaan Pengabdian Pada Masyarakat Pembinaan Secara Teknis terhadap Petani Sasaran (Kelompok Tani Sasaran)}

Penyuluhan akan dilaksanakan pada petani yang telah memiliki kelompok secara permanen. Materi penyuluhan akan disampaikan melalui diskusi kelompok terfokus (focus group discussion) atau FGD. Melalui metode FGD diberikan dengan menjelaskan dan memberikan kesempatan kepada setiap anggota dalam kelompok untuk mengemukakan pendapatnya, mengkritisi dan menyumbangkan pemikirannya terkait materi penyuluhan yang disuluhkan. Hal ini ditujukan untuk membangkitkan partisipasi aktif anggota kelompok dan menumbuhkan rasa tanggungjawab bersama terhadap hasil akhir atau kesepakatan terhadap materi yang didiskusikan. Dengan demikian materi penyuluhan yang telah didiskusikan merupakan milik atau gagasan bersama. Peran tim penyuluh adalah sebagai 
moderator, fasilitator dan nara sumber terkait materi, namun kesimpulan akhir akan dirumuskan secara bersama-sama oleh kelombok.

\section{Melakukan Peragaan dan Pelatihan}

Peragaan dan pelatihan akan dilakukan bersama-sama anggota kelompok, PPL, petugas Desa atau petugas Dusun di Desa sasaran dengan memperkenalkan materi penyuluhan sebagai berikut:

1. Prinsip Dasar Budidaya Tanaman Hortikultura (Sayuran).

Ada tiga prinsip dasar pertaian konservasi (FAO, 2018) yakni: 1) Mengolah tanah seminimal mungkin hingga tidak diolah sama sekali; 2) Menutup permukaan tanah serapat-rapatnya secara kontinyu sepanjang tahun; 3) Tumpang sari dan rotasi tanaman, terutama antara tanaman non legume dengan legume

2. Teknik Bedeng Permanen

Aplikasi teknik bedeng permanen mempunyai dampak positif terhadap peningkatan produktivitas lahan, serta berdampak baik terhadap peningkatan kinerja petani maupun gatra sosial ekonomi. Kinerja penerapan teknik bedeng permanen untuk mencegah kerusakan tanah akibat pengolahan yang berkelanjutan, selain itu dapat menghemat biaya pengolahan tanah.

3. Pengaruh Sistem Bedeng Permanen Terhadap Tanah dan Biaya

Tanah. Pengelolaan tanah minimal tidak merusak struktur tanah, selanjutnya pemberian pPenutup tanah dan pupuk organic dapat memperbaiki sifat kimia, fisik dan biologi tanah.

Biaya dan Tenaga Kerja. Biaya dan tenaga kerja berkurang karena tanah tidak diolah, penyiangan gulma, di samping itu penggunaan pupuk dan bahan kimia lainnya dapat ditekan penggunaannya sehingga dapat menekan biaya juga.

\section{Sasaran Pengabdian pada Masyarakat}

Sasaran pengabdian pada masyarakat adalah kelompok tani permanen yang melaksanakan kegiatan usaha tani di sawah, Desa Ombe baru, kecamatan Kediri Kabupaten Lombok Barat. Kelompok Tani ini adalah kelompok tani binaan yang belum mengenal teknik bedeng permanen. Materi yang akan mereka peroleh pada penyuluhan ini merupakan materi penyuluhan awal sebagai pengenalan. Kelompok tani sasaran adalah pelaku usaha tani pada lahan sawah yang belum mendapatkan materi penyuluhan terkait teknik bedeng permanen.

\section{Tahap Kegiatan Meliputi Tiga Tahap}

Tahap I: Melakukan tahap identifikasi masalah yang secara nyata dialami oleh kelompok tanai sasaran dan menyepakati kesiapan kelompok tani sebagai sasaran penyuluhan secara berkelanjutan

Tahap II: Merumuskan materi dan tema penyuluhan yang sesuai dengan masalah utama yang ada pada kelompok sasaran

Tahap III. Penyelenggaraan kegiatan penyuluhan, yang terdiri dari dua kegiatan, yaitu: (1) diskusi fokus grup (FGD) dalam rangka sinkronisasi antara materi yang disiapkan tim penyuluh dan pengalaman empiris yang dimiliki oleh anggota kelompok, dan (2) pelatihan dan peragaan teknis pertanian konservasi 


\section{HASIL DAN PEMBAHASAN}

\section{Permasalahan yang Dihadapi Kelompok Tani Kelangkaan Saprodi}

Petani di desa Ombe Baru umumnya baru mengenal teknik bedeng permanen dan dapat dikatakan tidak pernah menanam tanaman hortikultura seperti syuran. Sehingga kelangkaan dan ketersediaan saprodi seperti benih sering dialami pasara petani di lapangan. Hal ini menyebabkan petani harus mengeluarkan modal yang lebih besar karena harus membeli saprodi di luar desanya.

Infrastruktur penunjang budidaya tanaman hortikultura juga belum memadai, hal ini dapat terlihat dengan belum adanya saluran irigasi yang memadai untuk areal pertanaman dan masih bersifat konvensional.

\section{Permodalan}

Modal adalah masalah umum yang petani atau kelompoj tani sering hadapi. Petani jiika hendak memulai usahaninya selalu terbentur dengan permasalahan permodalan karena petani umumnya mempunyai lahan sempit dan tidak punya cukup modal, hal ini juga dikarena para petani mengalami gagal panen pada musim tanam sebelumnya. Sehingga petani memerlukan stimulus awal untuk memulai usahataninya di awal musim. Dalam hal ini peran Pemerintah untuk menyediakan permpodalan dan saprodi untuk sektor pertanian sangatlah penting.

\section{Pemasaran}

Masalah pemasaran adalah masalah umum yang sering dihadapi para petani baik perorangan atau kelompom tani (poktan) atau gabungan kelompok tani (gapoktan). Hal lain yang juga jadi kendala adalah tidak stabilnya harga produk pertanian secara umum dan hortikultura secara khusus, terutama pada saat musim panen. Tidak jaminan harga karena agribisnis umumnya mengikuti pasar yaitu: harga akan mahal jika hasil sedikit atau penawaran banyak dan sebaliknya harga menjadi rendah bila hasil berlimpah dan panawaran sedikit. Msalah ini yang sering dihadapi oleh petani sayuran. Untuk permasalahan ini pemerintah mempunyai peranan yang besar untuk membantu para petani, yaitu bagaimana pasar dapat menyerap hasil para petani tersebut.

\section{Inovasi yang Ditawarkan Pada Pemecehan Permasalahan}

Budidaya selalau diawal dengan pengolahan tanah (mencangkul dan atau pembajakan) tanah kemudian dilanjutkan dengan membentuk tanah menjadi bedeng dengan saluran drainasenya. Bedeng dibuat dengan tujuan agar air tanah dan unsur hara tidak cepat hilang dan jika hujan air tidak tergenang (untuk tanaman tidak tahan air).

Para petani seringkali kurang tepat dalam membuat bedengan, memang setiap petani mempunyai pengalaman yang berbeda-beda di lapangan dan mereka umumnya menjalankan apa yang umum dilakukan selama ini. Namun petani harus diberikan contoh bagaimana membuat bedengan yang baik terutama arah dan lebar bedengan untuk tanaman sayuran sehingga mereka dapat menirunya untuk seterusnya (Suriadikarta et al, 2002)

Berdasarkan pengalaman dan melihat ke lapangan langsung serta beberapa referensi, bahwa arah bedengan sebaiknya Utara-Selatan, hal ini bertujuan untuk mempermudah tanaman memperoleh Sinar Matahari untuk proses Fotosintesis. Hal ini akan membuat tanaman tumbuh dengan baik dan subur.

Teknik bertanam sayuran yang dilakukan oleh beberapa petani atau kelompok tani di lokasi pengabdian masih kurang hal ini dikarenakan para petani jarang atau bahkan tidak pernah menanam 
sayuran serta petani umumnya menanam padi, kacang-kacangan dan jagung. Sehingga hasil sayuran yang didapat juga jauh dari yang diharapkan. Padahal budidaya sayuran dengan teknik yang tepat juga dapat memberikan hasil yang baik dan menambah pendapatan bagi para petani.
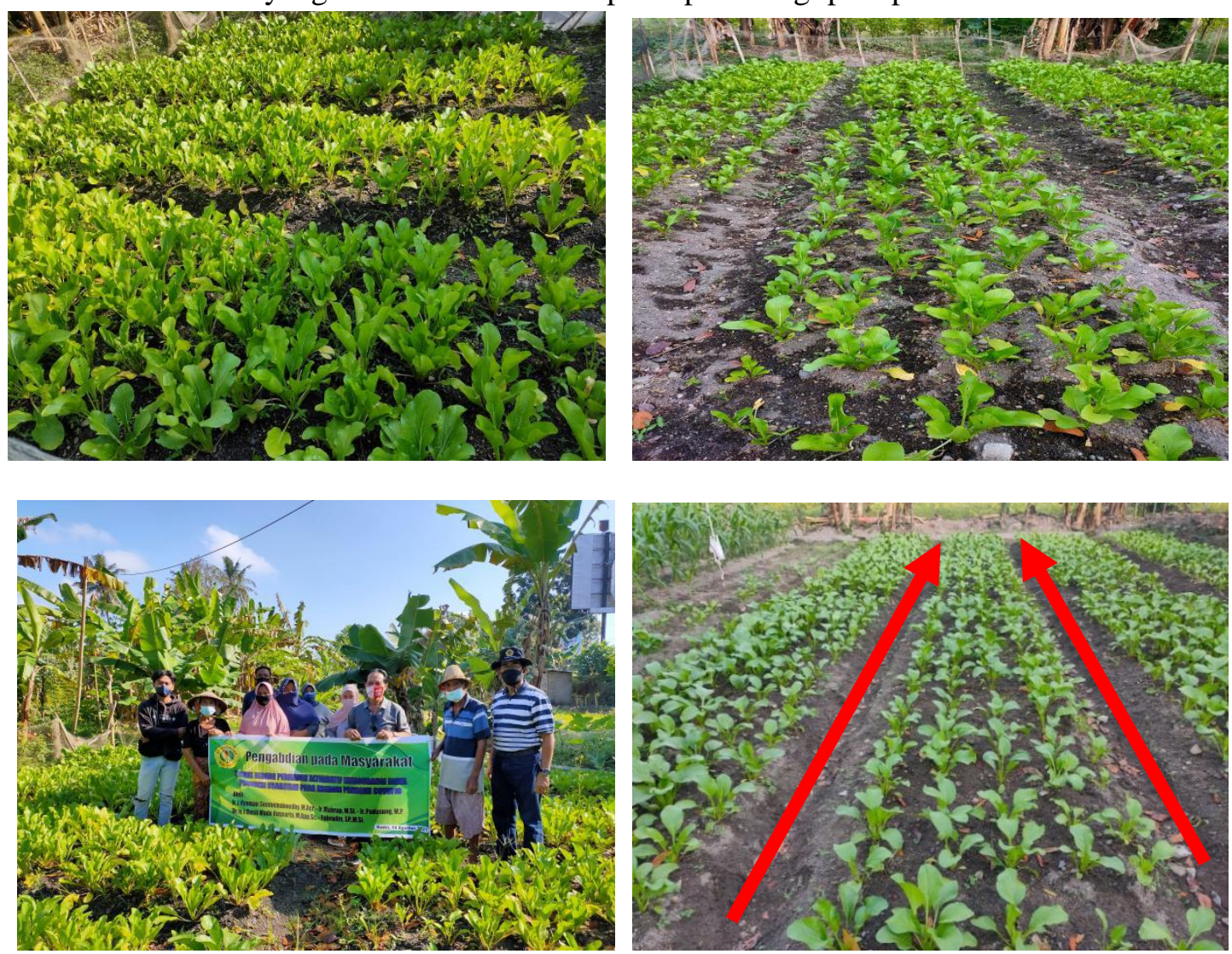

Gambar 1. Budidaya tanaman sayuran (Sawi) dengan teknik bedeng permanen.

Salah satu solusi yang ditawarkan pada penyuluhan ini adalah memanfaatkan Teknik Bedeng Permanen untuk tanaman sayuran, Solusi ini memberikan beberapa keuntungan dalam budidaya tanaman khususnya sayuran yaitu: 1) sayuran yang ditanam dapat ditanam secara tumpangsari dengan tanaman lain, 2) saluran diantara bedeng dapat digunakan sebagai penampung air (musim kemarau) dan pembuangan air (musim hujan), 3) budiaya tanaman dapat dengan beberapa jenis tanaman semusim, 4) bedeng dapat digunakan secara terus-menerus (3-4 musim tanam), 5) meningkatkan kualitas tanah akibat pengolahan tanahnya minim dan penggunaan pupuk organic (Rachman et al, 2004.)

\section{Analisis Tindak Lanjut Kelangsungan Inovasi yang Diterapkan Pada Kelompok Tani}

Data yang diperoleh dari hasil FGD kemudian di analisis menggunakan Analitical Hierarchy Process (AHP) untuk menilai respon petani terhadap penerapan teknologi yang disampaikan (disuluhkan), yaitu teknologi bercocoktanam Sistem Bedeng Permanen. Rangkuman hasil analisis tersebut disajikan pada Tabel 1. Hasil analisis AHP pada 4 kriteria pemilihan bedeng, dan alternatif pemilihan tanaman untuk ditanam pada SBP (seperti yang disebutkan di atas), maka dikatatakan bahwa petani di desa Ombe Lombok Barat, yang diwakili oleh kelompok tani Pade Angen, bersedia menerapkan SBP dengan dasar kriteria PA, HB, KP, dan KB, dengan prioritas tanaman adalah Sayur. Kemudian disusul berturut-turut oleh tanaman Kacang Panjang, Jagung, jagung masin, kacang tanah dan semangka atau melon, dan kacang panjang (Tabel 1). Pilihan tanaman ini cukup beralasan, karena 
dari segi harga, tanaman sayuran sangat menjanjikan, terutama dapat dibudidya dan dipanen beberapa kali, dimana kebutuhan sayuran terus meningkat setiap harinya. Semangka atau melon menjadi alternatif terakhir disebabkan karena kesulitas dari segi banyaknya jenis hama dan penyakit pada tanaman tanaman semangka.

Tabel 1. Kecenderungan penerimaan Petani terhadap Sistem Bedeng Permanen pada berbagai Kriteria dan dengan alternatif pilihan jenis tanaman yang disukai

\begin{tabular}{cccccc}
\hline & \multicolumn{5}{c}{ KRITERIA } \\
TANAMAN & PA & HB & KP & KB & \multirow{2}{*}{ Prioritas } \\
\hline SY & 0.25 & 0.24 & 0.23 & 0.32 & 0.26 \\
KCP & 0.20 & 0.19 & 0.26 & 0.23 & 0.22 \\
JG & 0.07 & 0.13 & 0.05 & 0.07 & 0.08 \\
JGM & 0.09 & 0.09 & 0.13 & 0.21 & 0.13 \\
KCT & 0.15 & 0.22 & 0.06 & 0.07 & 0.13 \\
SM & 0.18 & 0.13 & 0.19 & 0.07 & 0.14 \\
Jumlah & 1.00 & 1.00 & 1.00 & 1.00 & 1.00 \\
\hline
\end{tabular}

Keterangan: PA = Kriteria Penghematan air; KP = Kemudahan Pengelolaan

$\mathbf{P B}=$ Penghematan Biaya; $\mathbf{K B}=$ Kontinyuitas bertanam

$\mathrm{SY}=$ Alternatif tanaman Sayuran; $\mathrm{KCP}=$ Kacang Panjang

$\mathrm{JG}=$ Jagung; $J G M=$ Jagung Manis

$K C T=$ Kacang Tanah; $S M=$ Semangka

\section{Kesimpulan}

\section{KESIMPULAN DAN SARAN}

Berdasarkan hasil kegiatan pengabdian yang telah dilakukan hingga tahap sekarang ini, maka dapat disimpulkan beberapa hal sebagai berikut:

1. Kegiatan pengabdian kepada masyarakat petani di desa Ombe baru terlaksana sesuai harapan, sejak persiapan tanah penanaman, hingga penyampaian materi inti melalui FGD.

2. Kehadiran para anggota kelompok tani "Pade Angen" dalam kegiatan pengabdian ini walaupun dibatasi sangat tinggi, dan menunjukkan ketertarikan mereka untuk menerima teknologi Teknik Bedeng Permanen, ssudah mulai nampak.

3. Antusias para petani untuk mengetahui lebih lanjut teknik bedeng permanen cukup tinggi, hal ini terlihat dari banyaknya pertanyaan yang mendasar dan relevan pada permasalahan Teknik Bedeng Permanen.

\section{Saran}

Antusias para petani yang cukup tinggi merupakan langkah awal dalam proses adopsi terhadap paket teknologi yang disampaikan/diperkenalkan. Untuk menjamin kelangsungan proses adopsi tersebut, maka dukungan riil dari para pihak pemangku kepentingan, baik dari pemerintah daerah, tokoh agama, dan tokoh masyarakat untuk bahu-membahu dalam mengkawal introduksi teknologi yang bermanfaat bagi kemajuan dan perbaikan kondisi masyarakat sangat diperlukans.

\section{Ucapan Terima Kasih}

Ucapan terimakasih diucapkan kepada Ketua Lembaga Penelitian dan Pengabdian (LPPM) Universitas Mataram, Dekan Fakultas Pertanian Universitas Mataram dan Ketua BP3F Fakultas Pertanian Universitas Mataram. 


\section{DAFTAR PUSTAKA}

Abdurachman, A. dan S. Sutono. 2005. Teknologi pengendalian erosi lahan berlereng. hlm. 103-145. Dalam Teknologi Pengelolaan Lahan Kering: Menuju pertanian produktif dan ramah lingkungan. Pusat Penelitian dan Pengembangan Tanah dan Agroklimat, Bogor.

Adiningsih, S. dan Sudjadi. 1983. Pengaruh penggenangan dan pemupukan terhadap tanah podsolik Lampung Tengah. Jurnal Penelitian Tanah dan Pupuk 2. Puslittanak, Bogor.

Food Agriculture Organization (FAO). 2018. Pertanian Konservasi (Perinsip Dasar dan Petunjuk Praktis). FAO. 2018.

Las, I., S. Purba, B. Sugiharto, dan A. Hamdani 2000. Proyeksi kebutuhan dan pasokan pangan tahun 2000-2020. Pusat Penelitian Tanah dan Agroklimat, Bogor.

Kusnarta, I.G.M., B.D. Kertonegoro, B.H. Sunarminto, dan D. Indradewa, 2011. Beberapa Faktor yang berpengaruh Dominan terhadap Struktur Vertisol Tadah Hujan Lombok. Agroteksos Jurnal Ilmiah Ilmu Pertanian, Vol. 21, No. 2-3, pp:120-128.

Mulyani, A., Hikmatullah, dan H. Subagyo. 2004. Karakteristik dan potensi tanah masam lahan kering di Indonesia. hlm. 1-32 dalam Prosiding Simposium Nasional Pendayagunaan Tanah Masam. Pusat Penelitian dan Pengembangan Tanah dan Agroklimat, Bogor.

Rachman, A, A. Dariah, dan E. Husen. 2004. Olah Tanah Konservasi. Hlm.189210 dalam Konservasi Tanah pada Lahan Kering Berlereng. PusatPenelitian dan Pengembangan Tanah dan Agroklimat. Badan LitbangPertanian. Departemen Pertanian.

Soepardi, H.G. 2001. Strategi usaha tani agribisnis berbasis sumber daya lahan. hlm. 35- 52. Prosiding Nasional Pengelolaan Sumber Daya Lahan dan Pupuk Buku I. Pusat Penelitian dan Pengembangan Tanah dan Agroklimat, Bogor.

Sukmana, S. 1994. Budi daya lahan kering ditinjau dari konservasi tanah. hlm. 25-39. Dalam Prosiding Penanganan Lahan Kering Marginal melalui Pola Usaha Tani Terpadu. Jambi, 2 Juli 1994. Pusat Penelitian Tanah dan Agroklimat, Bogor.

Sukmana, S. 1995. Teknik konservasi tanah dalam penanggulangan degradasi tanah pertanian lahan kering. hlm. 23-42. Dalam Prosiding Pertemuan Pembahasan dan Komunikasi Hasil Penelitian Tanah dan Agroklimat. Pusat Penelitian Tanah dan Agroklimat, Bogor.

Suriadikarta, D.A., T. Prihatini, D. Setyorini, dan W. Hartatiek. 2002. Teknologi pengelolaan bahan organik tanah. hlm. 183-238. Dalam Teknologi Pengelolaan Lahan Kering Menuju Pertanian Produktif dan Ramah Lingkungan. Pusat Penelitian dan Pengembangan Tanah dan Agroklimat, Bogor.

Pusat Penelitian dan Pengembangan Tanah dan Agroklimat. Kebijakan dan Impelentasi Tata Ruang Daerah Pertanian Tingkat Nasional. Bogor. 2001. 